\title{
Head of US watchdog faces uncertain future
}

\section{Washington}

The controversial head of the US government office that oversees the protection of human research subjects is likely to find himself out of a job in the coming months, when the office is dissolved and reconstituted in the office of Donna Shalala, the Secretary of Health and Human Services (HHS).

Gary Ellis, director of the Office for Protection from Research Risks (OPRR) at the National Institutes of Health (NIH), has overseen an unprecedented series of recent research shutdowns at universities, including major institutions such as the Duke University Medical Center (see Nature 399, 190; 1999).

The latest came last week, when the OPRR suspended some 550 federally funded researchers at the University of Alabama at Birmingham. The office has charged that the targeted universities are not living up to the government's requirements for protecting human subjects. The shutdowns have cost the institutions concerned millions of dollars.

But Ellis's supporters say he faces punishment for his activities when the OPRR is dissolved and responsibility transferred to Shalala's office. The move was recommended by a panel of advisers to Harold Varmus, then the NIH director, in a report last June (see Nature 399, 514; 1999).

According to Ellis's backers, top NIH officials are using the move as an opportunity to press for the installation of a more research-friendly 'human subjects tsar' as director of the new office, to be called the 'Office for Human Research Protections'. The NIH declines to comment, except to say through a spokesman that "the search for the OPRR director is entirely in the hands of the office of the secretary".

Arthur Lawrence, the deputy assistantsecretary for health operations at HHS, says he has "no basis" for responding to the allegation. But he points out that HHS is hiring for "a completely new job", and that a wide search for qualified applicants is therefore appropriate. The job is a senior position in executive service, ranking above the current OPRR director in power and pay.

The job description posted by HHS calls for a "statesman" with "national recognition for his/her accomplishments in scientific research". Arthur Caplan, director of the Center for Bioethics at the University of Pennsylvania, notes that the requirement for a statesman "might exclude someone like Gary Ellis, who is clearly doing a good job”.

Ellis, 45, has a PhD from Northwestern University in biological sciences and specialized in medical reproductive endocrinology as a postdoc. He came to Washington as a science and health policy researcher in 1983, and has directed OPRR since 1993.
The OPRR has disciplined more than 10 per cent of the nation's medical schools during Ellis's tenure. The pace and severity of its sanctions grew dramatically after the HHS inspector general issued a voluminous report in June 1998 arguing that the system for ensuring protection for human subjects was "in jeopardy". Members of Congress have argued that federal watchdogs were failing to do their part to enforce protection (see Nature 393, 610; 1998).

Since October 1998, Ellis's office has shut down federally funded research for varying periods at seven institutions, of which Duke and the University of Illinois at Chicago are the most prominent. But researchers and institution officials have complained that the offences for which they were shut down were infractions related to procedure and paperwork, and that the punishment has been out of proportion to the offence because subjects had not been exploited.

To suspend all research at an institution is "devastating", says Robert Levine, a professor of medicine at the Yale University School of Medicine and chair of the Yale medical school committee that reviews the ethics of experiments with human subjects. Levine has been asked by HHS to apply for the new director's job. Ellis declines to comment, except to say that he is applying for the post.

Meredith Wadman

\section{Top UK epidemiologist suspended after complaints}

\section{London}

Roy Anderson, a professor of zoology at the University of Oxford and the director of the Wellcome Trust Centre for the Epidemiology of Infectious Disease, has been suspended on full pay following formal complaints from two female members of his staff.

Paul Harvey, the head of the zoology department, says that the suspension is a "neutral move while the allegations are under investigation and so do not say anything about innocence or guilt".

The suspension follows an investigation and preliminary report by university officials to the registrar and vice-chancellor, who have apparently decided there is a case to be answered.

The case centres on an appointment to a readership in epidemiology at the end of last year. The position went to Sunetra Gupta, considered by the appointment committee as the best candidate. As well as a highly regarded scientist, Gupta is perhaps better known as a novelist - her most recent book, A Sin of Colour, came out last year.

In early December, Gupta filed a

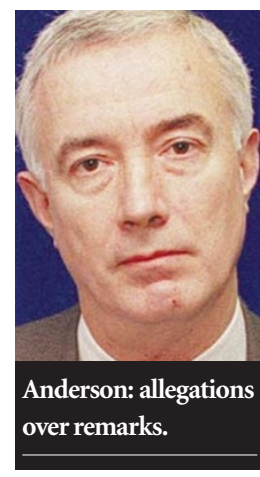

complaint which is said to concern public allegations made by Anderson on the means by which she had obtained her appointment and on her relationship with Harvey. The delivery of the preliminary report initiates procedures that look likely to lead to a private

disciplinary hearing.

Anderson is a senior figure in UK biomedical research and an expert on the epidemiology of BSE (see Nature 392, 533; 1998). He was head of the zoology department at Oxford during 1993-98, and has been director of the Wellcome Trust centre there since 1994 .

The university issued a statement last week confirming that a director of "one of the university's research centres" had been

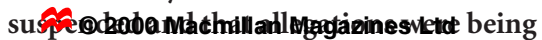
investigated under its statutory procedures.
"We can't say very much because it would be wrong to prejudge the points that will be made at the various stages of this process," says a university spokesperson. "Suspension is basically a step to mean that everyone can, as much as possible in these situations, get on with their work."

A member of the university with legal experience, and four senior members of the University's Congregation - the 'parliament of dons' that has final responsibility for all legislative matters will chair a hearing. Anderson may attend this hearing, have representation and call and question witnesses.

The timescale for the disciplinary hearing is not yet known. But a university spokesperson said, “it is in everyone's interest it is done as quickly as possible, but there are practical issues to do with getting together the people needed".

Another researcher at the Wellcome Trust centre has complained about Anderson's comments on the appointments process. Attempts last week to contact both Anderson and Gupta were unsuccessful. 